IJAMSR 3 (9) www.ijamsr.com CrossRef: https://doi.org/10.31426/ijamsr.2020.3.9.3711

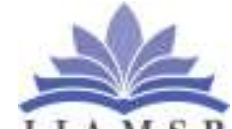

International Journal of

I J A M S R

Advanced Multidisciplinary Scientific Research (IJAMSR) ISSN:2581-4281

\title{
Service Quality In Public Sector Hospitals: The Kashmiri Patients' Perspective
}

\section{Syed Shoaib}

Ph. D Research Scholar, Dept. of Management, Shri Venkateshwara University, U.P., India

Email: Shoaib.cyed@gmail.com

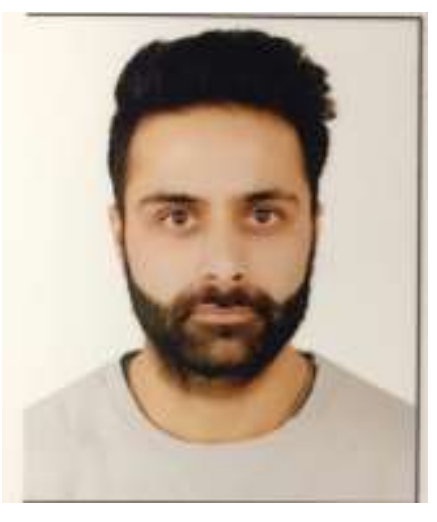

SYEd SHOAIB

\section{Keywords:}

Public Sector Hospitals, Kashmiri Patients' Perspective, Service Quality

\section{A B S T RA C T}

A health care institute, determined at providing specialized treatment to patients with the help of professional staff and medical equipment. Perhaps this statement would be ample to describe a hospital in words. A glance in the historic past tells us that since the dawn of civilization, illness, diseases and wounds have been companions of human beings. Although diseases and wounds were treated well to a certain extent in the past, yet the approaches taken in the present are of course different. Summing up all it could be said that where there is a sickness, there is a treatment too. Every human being, at least once in a lifetime must have been associated with a hospital. Since hospitals provide patients with services such as treatments, medical counselling, testing etcetera, there is definitely a quality of service associated with the services they offer. This study is contemplated to evaluate the service quality offered by the public sector hospitals in Kashmir. The model that has been used to evaluate the said service quality was the SERVQUAL model of service quality by (Parasuraman, Zeithaml, \& Berry, 1988). Patients are the primary agents who can appraise and assess the quality of services in hospitals; therefore, in consonance with the Servqual model, a questionnaire was developed on a 5-point Likert type scale consisting of 44 problem variables, distributed in all the five dimensions of the model. The primary data was collected through this structured questionnaire and the responses so obtained were analysed through the most reliable statistical tool SPSS (ver.20).

Citation: Syed Shoaib (2020). Service Quality In Public Sector Hospitals: The Kashmiri Patients' Perspective. International Journal of Advanced Multidisciplinary Scientific Research (IJAMSR) ISSN:25814281, 3 (9), September 2020, Pp 1 - 12 
IJAMSR 3 (9) www.ijamsr.com CrossRef: https://doi.org/10.31426/ijamsr.2020.3.9.3711

\section{International Journal of}

Advanced Multidisciplinary Scientific Research (IJAMSR) ISSN:2581-4281

\section{Introduction:}

It is human beings who run a nation, and therefore, its development and prosperity depends on its human resources. In view of this fact, every country should have an appropriately developed government health sector, and, therefore, special health care facilities should be provided to every individual. In the modern world, evaluation of service quality in the health care sector has become the most significantly important subject. The assessment of quality of service depends on the perceptions of patients. They evaluate the difference between expectations and perceptions they associate with the hospitals. This difference is the actual performance of hospitals in terms of the services delivered to patients. The greater the perceptions are from expectations, the higher is the quality of services delivered.

Service quality has been a matter of debate since the concept of services has emerged. Being a pivotal element in patient satisfaction, service quality provides hospitals with a competitive advantage (Zarie et al., 2011). Therefore, it becomes essential for healthcare service providers to recognize needs and expectations of patients in order to serve them better leading towards greater satisfaction of patients. In a study "The Mediating Effect of Patient Satisfaction in the Patients' Perceptions of Healthcare Quality - Patient Trust Relationship", by (Alrubaiee \& Alkaa'ida, 2011), it is argued that a healthcare provider can earn trust of a patient by providing superior service quality aimed at greater patient satisfaction. Moreover, the greater the patient satisfaction achieved, the stronger is the association between the trust of the patient and the quality of healthcare service delivered. The ever increasing population makes it mandatory for the healthcare sector to constantly improve the services and deliver better service quality.

The valley of Kashmir houses many private and public sector hospitals. Also, sometimes referred to as the zone of conflict, the valley of Kashmir has suffered through many unfavourable circumstances such as strikes, curfews, bandhs, and many other disturbances which have altogether significantly affected the valley in almost every sector, be it health care, education or tourism. The valley of Kashmir has turned into a nerve center for many disorders such as diabetes, hypertension, hypothyroidism, cancer and many more. In respect to this, healthcare services in Kashmir 
IJAMSR 3 (9) www.ijamsr.com CrossRef: https://doi.org/10.31426/ijamsr.2020.3.9.3711

have not been up to the mark of satisfaction. The difference between the economically good and average classes is apparent in the healthcare sector quite well. An economically sound class that can afford private sector hospitals avails the desired service at will, while the lower income class is left out at the mercy of nature. For the inclusion of every individual in the healthcare sector, public hospitals are required to be able to deliver high quality services. Aimed at evaluating such a relationship between healthcare service providers and patients, this research intends to find out the quality of services delivered to patients and thus patient satisfaction achieved in due course.

\section{Literature Review}

There is adequate literature which shows the magnitude of work done by eminent researchers in the field of service quality. Since this study intends to use the SERVQUAL model of service quality by (Parasuraman, Zeithaml, \& Berry, 1988), therefore, a literature review based on the SERVQUAL model has been done. The Servqual model is actually a 22-item instrument which was established with the purpose of measuring customers' perception of service quality in the services sector (Parasuraman, Zeithaml, \& Berry, 1988). In the view of the developers of this model, service quality is a multidimensional conception which is perceived and appraised by consumers in accordance to a standard array of imperative factors, originally assembled in ten categories (1985) and later in only five levels (1988). The 22 -items of the instrument are distributed in five facets known as the dimensions of service quality and these dimensions are: (i) Tangibles (ii) Reliability (iii) Responsiveness (iv) Assurance, and (v) Empathy. Also known as the gaps model of service quality, the Servqual model was first published by Parasuraman, Zeithaml \& Berry in 1985, yet many changes have been brought to this model by its authors over the years such as in 1988, followed by 1991, 1994 etcetera. Ever since this model was established, it has been employed in varied researches which were aimed at evaluating the service quality.

A study conducted by (Punnakitikashem et al., 2012) used Servqual model to assess the service quality of hospitals. The overall perception of patients was found marginally smaller than their expectations. The gap analysis evaluated that the difference between perceptions and expectations was insignificant. 
IJAMSR 3 (9) www.ijamsr.com CrossRef: https://doi.org/10.31426/ijamsr.2020.3.9.3711

Among all the five dimensions of Servqual model, tangibility and reliability were found to be significantly important as perceived by the patients while assurance as a dimension was found to have the largest negative gap, suggested the study.

Another study "Service quality of private hospitals: The Iranian Patients' perspective", conducted by (Zarie et al., 2012), acknowledged the reliability and validity of the Servqual model in measuring the service quality in private sector hospitals. The study suggested that the private hospitals in Iran need to focus more on the areas concerning tangibility, reliability and empathy.

(Sayed, Mohamed, \& Mohamed, 2013), conducted a study on a public sector hospital in Makkah Al Mukarammah, Saudi Arabia using the Servqual model of service quality. The study revealed that patients were actually satisfied with the quality of service delivered. The highest satisfactory dimensions were reliability followed by assurance, tangibility and empathy while as the lowest satisfactory dimension was found to be responsiveness.

A study, "Adapting the Servqual scale to hospital services: an empirical investigation of patients' perceptions of service quality", by (Brahmbhatt, Baser, \& Joshi, 2011) was also carried out using Servqual model in both private and public sector hospitals in India. This study concluded that hospitals both in the private sector, as well as in the public sector have an unsatisfactory service quality. Significantly negative gaps were found in both the sectors. As is evident from literature review, much work has not been done in the public sector hospitals in the Valley of Kashmir in respect to the service quality, thus, making it essential for a study to be conducted in this sphere.

\section{Research Methodology}

For the study at hand, data was collected through primary sources i.e., from people who had availed the services of the public sector hospitals. The Servqual instrument consisting of two sections having 22-items each, purposed at evaluating expectations and perceptions respectively was used. Certain demographic variables were also added for the purpose of learning the respondents' demographic profile. 200 questionnaires were randomly distributed out of which 178 were received back. After careful consolidation, only 152 responses were found feasible for data analysis. 
IJAMSR 3 (9) www.ijamsr.com CrossRef: https://doi.org/10.31426/ijamsr.2020.3.9.3711

For the secondary data, many journal articles, research papers and internet websites were consulted. The data so collected was analysed using spss (ver.20). Data analysis techniques used in the study included Cronbach's alpha coefficient, Kaiser-Meyer-Olkin measure of sampling adequacy and Bartlett's test of spherecity, Factor analysis, t-test, frequency, mean and gap analysis.

\section{Results and Findings}

To check the reliability and validity of the research instrument used, a reliability/ internal consistency analysis was performed using Cronbach's alpha coefficient. This analysis was performed on both expectations and perceptions separately.

The coefficient of alpha although ranges from 0 to 1 , the accepted threshold for $\alpha$ is .70 (Nunnally and Bernstein, 1994), however, even lower values (in the .60's) are common (Peterson, 1994). Table 1 and Table 2 show coefficient of alpha for this study returned to be .984 in case of the instrument used to measure expectations and .977 for the instrument used to evaluate the perceptions of patients which is as per standards excellent.
After data analysis, frequencies based on the demographic profile of respondents was observed and presented here in the form of charts.

Table 3 shows that a total of 152 responses were analysed, out of which 88 were males comprising of approximately 58percent of the sample size and 64 were females which made up approximately 42 percent of the sample size.

Table 4 shows that majority of the respondents were of the age group between 21-30 years forming $\mathrm{n}=92$ of the total sample contributing approximately 61percent of the sample size.

In table 5 it is apparent that majority of the respondents were either graduates or post graduates with $\mathrm{n}=49$ and $\mathrm{n}=83$ respectively among which the highest were the post graduates forming over 50percent of the total sample size followed by graduates with 32percent. Moreover, approximately 60percent of the respondents were students forming the major part of the sample size while the least contributing were either public sector or private sector employees forming less than 10 percent of the total sample size of 152 as shown in table 6 . 
IJAMSR 3 (9) www.ijamsr.com CrossRef: https://doi.org/10.31426/ijamsr.2020.3.9.3711

Table 7 shows the annual household income of the respondents where it could be seen that the number of respondents having an annual household income of 2.5lacs and below were $\mathrm{n}=72$ forming approximately 47 percent of the sample size. The least number of respondents belonged to the income group of 10lacs and above with $\mathrm{n}=14$ forming approximately 9 percent of the sample size.

Furthermore, Keyser-Meyer-Olkin measure of sampling adequacy test was performed in order to assess how well the data was suited for factor analysis, (table 8). The values of KMO range from 0 to 1 where a score of .49 and below is considered unacceptable and .90 and above is considered marvellous.

Since the KMO test returned the results of .931 which means that the data was best suited for factor analysis. Moreover, Bartlett's test of Sphericity (table 8) was also run in order to identify if correlations are present among variables. If the significance values are lesser than 0.05 , it is an indication that the data is suited for factor analysis. Since the results of the test revealed that the values of significance are .000 which is far lesser than the threshold value of 0.05 , therefore, validating the suitability of data for factor analysis.
For the purpose of evaluating the actual service quality in the public sector hospitals of Kashmir, gap analysis was performed. Gap analysis compares the actual service quality being offered with the expected service quality. The higher the positive gap is, the satisfied the patient is and vice versa.

Table 9 shows the analysis of gaps with the correlation significant at $<0.05$. The gaps were calculated for every individual dimension and it was found that the gap score for every dimension scored significantly negative. Dimension wise, for tangibility the largest significantly negative gap was scored by item 4 which was concerned with the cleanliness and hygiene of the washrooms in the hospitals, while as the lowest significant and negative gap was found in item 2, which was concerned with the physical appearance of the hospital. Overall, it implied that lack of hygiene and cleanliness in hospital washrooms contributed the most to the tangibility gap. Moving towards the next dimension, reliability, the largest significantly negative gap was found in item 9 concerned about hospitals having error free and accurate records, and, the smallest negative and significant gap was found in item 7 which was related to hospitals performing services right 
IJAMSR 3 (9) www.ijamsr.com CrossRef: https://doi.org/10.31426/ijamsr.2020.3.9.3711

the first time. Item number 12 showed the highest negative and significant gap in responsiveness dimension whereas item number 10 recorded the smallest negative gap concerned with whether the hospital staff should always be willing to help patients and should the hospital staff tell patients when exactly the service will be provided respectively. Referring to the assurance dimension, item 16 recorded the highest significantly negative gap, concerned with the hospital staff being polite. Relatively, item 15 had the smallest negative and significant gap in the same dimension which measured whether the clients of the hospital feel safe in the transactions with the hospital staff. Item number 18 in the empathy dimension had the largest negative and significant gap concerning whether the staff of hospitals should give patients individual attention or not, whereas, item 19 has the smallest significantly negative gap referring to the hospitals having round the clock working hours or not.

If we take a look at overall gap scores, empathy dimension reveals to have the smallest negative and significant gap while as on the other hand, tangibility and assurance recorded equally highest negative and significant gaps.

Table 10 shows the overall service quality and the dimension-wise breakup of service quality gaps. Since all the dimensions score perfectly negative and significant in the gap analysis, it can be interpreted that all the five dimensions contribute remarkably in the overall service quality gap. Moreover, the average gap score was found out to be significant and high negative, henceforth, implied that the patients are highly dissatisfied with the quality of service delivered in public sector hospitals in Kashmir.

\section{Conclusion and Recommendations}

This study has explored the magnitude of service quality being delivered in public sector hospitals in the Valley of Kashmir through the framework of the Servqual model of service quality. Using a valid and reliable research instrument, the data analysis of over 150 respondents helped to chart out that there are significant negative gaps in all the five dimensions of the Servqual model representing overall customer dissatisfaction. The overall average gap score was a perfect negative and highly significant number thus, again pointing 
IJAMSR 3 (9) www.ijamsr.com CrossRef: https://doi.org/10.31426/ijamsr.2020.3.9.3711

\section{International Journal of Advanced Multidisciplinary Scientific Research (IJAMSR) ISSN:2581-4281}

towards patients' dissatisfaction from the service quality in the public sector hospitals of the Kashmir valley.

As a part of this research, it is recommended for all the public sector hospitals of the valley to concentrate on all the dimensions equally with an aim of improving the service quality. Patients' feedback plays an important part in evaluating the loopholes in service quality being offered, therefore, a proper feedback mechanism facilitated by a grievance redressal mechanism should be adopted by the public sector hospitals in the valley.

\section{Tables}

\begin{tabular}{|l|l|}
\hline \multicolumn{2}{|c|}{ Table:1 Reliability Statistics (Expected) } \\
\hline Cronbach's Alpha & N of Items \\
\hline .984 & \\
\hline
\end{tabular}

\begin{tabular}{|l|l|}
\hline \multicolumn{2}{|l|}{ Table:2 Reliability Statistics (Perceived) } \\
\hline Cronbach's Alpha & N of Items \\
\hline .977 & \\
\hline
\end{tabular}

Table:3 Gender

\begin{tabular}{|l|l|r|r|r|r|}
\hline \multicolumn{2}{|c|}{} & \multicolumn{1}{|c|}{ Frequency } & \multicolumn{1}{|c|}{ Percent } & Valid Percent & $\begin{array}{c}\text { Cumulative } \\
\text { Percent }\end{array}$ \\
\hline \multirow{4}{*}{ Valid } & Male & 88 & 57.9 & 57.9 & 57.9 \\
\cline { 2 - 7 } & Female & 64 & 42.1 & 42.1 & 100.0 \\
\cline { 2 - 6 } & Total & 152 & 100.0 & 100.0 & \\
\hline
\end{tabular}


International Journal of Advanced Multidisciplinary Scientific Research (IJAMSR) ISSN:2581-4281 Volume 3, Issue 9, September 2020

IJAMSR 3 (9) www.ijamsr.com CrossRef: https://doi.org/10.31426/ijamsr.2020.3.9.3711

International Journal of

I J A M S R Advanced Multidisciplinary Scientific Research (IJAMSR) ISSN:2581-4281

\begin{tabular}{|l|l|r|r|r|r|}
\hline \multicolumn{2}{|c|}{ Table:4 Age } \\
\hline \multicolumn{1}{|c|}{ Frequency } & Percent & Valid Percent & \multicolumn{1}{c|}{$\begin{array}{c}\text { Cumulative } \\
\text { Percent }\end{array}$} \\
\hline \multirow{4}{*}{ Valid } & 20 \& below & 18 & 11.8 & 11.8 & 11.8 \\
\cline { 2 - 6 } & $21-30$ & 92 & 60.5 & 60.5 & 72.4 \\
\cline { 2 - 6 } & $31-40$ & 39 & 25.7 & 25.7 & 98.0 \\
\cline { 2 - 6 } & $41-50$ & 3 & 2.0 & 2.0 & 100.0 \\
\cline { 2 - 6 } & Total & 152 & 100.0 & 100.0 & \\
\hline
\end{tabular}

\begin{tabular}{|r|l|r|r|r|r|}
\hline \multicolumn{2}{|c|}{ Table:5 Education } \\
\hline \multirow{3}{*}{} & Frequency & Percent & Valid Percent & $\begin{array}{c}\text { Cumulative } \\
\text { Percent }\end{array}$ \\
\hline \multirow{5}{*}{ Valid } & Secondary Education & 10 & 6.6 & 6.6 & 6.6 \\
\cline { 2 - 6 } & Graduate & 49 & 32.2 & 32.2 & 38.8 \\
\cline { 2 - 6 } & Post Graduate & 83 & 54.6 & 54.6 & 93.4 \\
\cline { 2 - 6 } & Others & 10 & 6.6 & 6.6 & 100.0 \\
\cline { 2 - 6 } & Total & 152 & 100.0 & 100.0 & \\
\hline
\end{tabular}

\begin{tabular}{|c|c|c|c|c|c|}
\hline \multicolumn{6}{|c|}{ Table:6 Profession } \\
\hline & & Frequency & Percent & Valid Percent & $\begin{array}{c}\text { Cumulative } \\
\text { Percent }\end{array}$ \\
\hline \multirow{5}{*}{ Valid } & \begin{tabular}{|l|} 
Student \\
\end{tabular} & 90 & 59.2 & 59.2 & 59.2 \\
\hline & Self Employed & 43 & 28.3 & 28.3 & 87.5 \\
\hline & $\begin{array}{l}\text { Public/ Private Sector } \\
\text { Employee }\end{array}$ & 9 & 5.9 & 5.9 & 93.4 \\
\hline & Others & 10 & 6.6 & 6.6 & 100.0 \\
\hline & Total & 152 & 100.0 & 100.0 & \\
\hline
\end{tabular}


IJAMSR 3 (9) www.ijamsr.com CrossRef: https://doi.org/10.31426/ijamsr.2020.3.9.3711

\section{International Journal of}

Advanced Multidisciplinary Scientific Research (IJAMSR) ISSN:2581-4281

\begin{tabular}{|c|c|c|c|c|c|}
\hline \multicolumn{6}{|c|}{ Table:7 Annual Income } \\
\hline & & Frequency & Percent & Valid Percent & $\begin{array}{c}\text { Cumulative } \\
\text { Percent }\end{array}$ \\
\hline \multirow{5}{*}{ Valid } & 2.5 lacs \& below & 72 & 47.4 & 47.7 & 47.7 \\
\hline & 2.6-5.0 lacs & 36 & 23.7 & 23.8 & 71.5 \\
\hline & 5.1-10.0 lacs & 29 & 19.1 & 19.2 & 90.7 \\
\hline & 10 lacs \& above & 14 & 9.2 & 9.3 & 100.0 \\
\hline & Total & 151 & 99.3 & 100.0 & \\
\hline Missing & System & 1 & .7 & & \\
\hline \multicolumn{2}{|l|}{ Total } & 152 & 100.0 & & \\
\hline
\end{tabular}

\section{Table:8 KMO and Bartlett's Test}

Kaiser-Meyer-Olkin Measure of Sampling Adequacy.

Bartlett's Test of Sphericity

\begin{tabular}{|l} 
Approx. Chi-Square \\
\hline df \\
\hline Sig.
\end{tabular}


International Journal of Advanced Multidisciplinary Scientific Research (IJAMSR) ISSN:2581 -4281 Volume 3, Issue 9, September 2020

IJAMSR 3 (9) www.ijamsr.com CrossRef: https://doi.org/10.31426/ijamsr.2020.3.9.3711

\section{International Journal of}

Advanced Multidisciplinary Scientific Research (IJAMSR) ISSN:2581-4281

Table: 9 GAP Analysis

\begin{tabular}{|c|c|c|c|c|c|c|}
\hline $\begin{array}{c}\text { Quality } \\
\text { Dimension }\end{array}$ & Item & $\begin{array}{c}\text { Average } \\
\text { Perceived }\end{array}$ & $\begin{array}{l}\text { Average } \\
\text { Expected }\end{array}$ & $\begin{array}{c}\text { Average } \\
\text { Gap }\end{array}$ & t-value & P-value \\
\hline \multirow[t]{4}{*}{ Tangibility } & 1 & 3.13 & 4.43 & -1.303 & -10.400 & .000 \\
\hline & 2 & 3.28 & 4.28 & -1.000 & -7.428 & .000 \\
\hline & 3 & 3.29 & 4.49 & -1.204 & -10.217 & .000 \\
\hline & 4 & 2.74 & 4.48 & -1.743 & -11.398 & .000 \\
\hline \multirow[t]{5}{*}{ Reliability } & 5 & 3.16 & 4.42 & -1.263 & -10.356 & .000 \\
\hline & 6 & 3.34 & 4.46 & -1.125 & -10.247 & .000 \\
\hline & 7 & 3.25 & 4.34 & -1.092 & -8.964 & .000 \\
\hline & 8 & 3.31 & 4.51 & -1.204 & -10.348 & .000 \\
\hline & 9 & 3.25 & 4.53 & -1.276 & -11.156 & .000 \\
\hline \multirow[t]{4}{*}{ Responsiveness } & 10 & 3.15 & 4.39 & -1.237 & -9.283 & .000 \\
\hline & 11 & 3.14 & 4.45 & -1.316 & -10.188 & .000 \\
\hline & 12 & 3.09 & 4.48 & -1.388 & -11.682 & .000 \\
\hline & 13 & 3.03 & 4.31 & -1.276 & -10.157 & .000 \\
\hline \multirow[t]{4}{*}{ Assurance } & 14 & 3.09 & 4.42 & -1.336 & -9.759 & .000 \\
\hline & 15 & 3.41 & 4.50 & -1.086 & -9.626 & .000 \\
\hline & 16 & 2.97 & 4.59 & -1.618 & -13.884 & .000 \\
\hline & 17 & 3.36 & 4.54 & -1.184 & -10.861 & .000 \\
\hline \multirow[t]{5}{*}{ Empathy } & 18 & 2.90 & 4.25 & -1.349 & -10.474 & .000 \\
\hline & 19 & 3.60 & 4.49 & -.888 & -8.890 & .000 \\
\hline & 20 & 3.22 & 4.44 & -1.224 & -10.591 & .000 \\
\hline & 21 & 3.23 & 4.40 & -1.171 & -10.217 & .000 \\
\hline & 22 & 2.91 & 4.08 & -1.164 & -9.016 & .000 \\
\hline
\end{tabular}


IJAMSR 3 (9) www.ijamsr.com CrossRef: https://doi.org/10.31426/ijamsr.2020.3.9.3711

International Journal of

Advanced Multidisciplinary Scientific Research (IJAMSR) ISSN:2581-4281

Table: 10 Overall Gaps and Service Quality

\begin{tabular}{|l|c|c|c|c|c|}
\hline \multicolumn{1}{|c|}{ Quality Dimension } & $\begin{array}{c}\text { Perceived } \\
\text { Average }\end{array}$ & $\begin{array}{c}\text { Expected } \\
\text { Average }\end{array}$ & Average Gap & t-value & P-value \\
\hline Tangibility & 3.10 & 4.42 & -1.32 & -11.320 & .000 \\
\hline Reliability & 3.26 & 4.45 & -1.19 & -12.014 & .000 \\
\hline Responsiveness & 3.10 & 4.40 & -1.30 & -11.705 & .000 \\
\hline Assurance & 3.20 & 4.51 & -1.31 & -12.323 & .000 \\
\hline Empathy & 3.17 & 4.33 & -1.16 & -11.521 & .000 \\
\hline Overall Service Quality & $\mathbf{3 . 1 6 6}$ & $\mathbf{4 . 4 2 2}$ & $\mathbf{- 1 . 2 5 6}$ & $\mathbf{- 1 1 . 7 7 7}$ & $\mathbf{. 0 0 0}$ \\
\hline
\end{tabular}

\section{References}

1) Alrubaiee, L., \& Alkaa'ida, F. (2011). The Mediating Effect of Patient Satisfaction in the Patients' Perceptions of Healthcare Quality - Patient Trust Relationship. International Journal of Marketing Studies , 3 (1), 103-127.

2) Brahmbhatt, M., Baser, N., \& Joshi, N. (2011). Adapting the SERVQUAL Scale to Hospital Services: An Empirical Investigation of Patients' Perceptions of Service Quality. International Journal of Multidisciplinary Research , 1 (8), 27-42.

3) Nunnally, J. C., \& Bernstein, I. H. (1994). Psychometric Theory 3rd Edition. New York: McGraw-Hill, Inc.

4) Parasuraman, A., Zeithaml, V., \& Berry, L. (1988). Servqual: A Multiple Item Scale for Measuring Consumer Peception. Journal of Retailing , 64, 12.

5) Peterson, R. A. (1994). A Meta-Analysis of Cronbach's Coefficient Alpha. Journal of Consumer Research, 21 (2), 381-391.

6) Punnakitikashem, P., Buavaraporn, N., Maluesri, P., \& Leelartapin, K. (2012). Health Care Service Quality: Case Example of a Hospital with Lean Implementation. POMS 23rd Annual Conference. Chicago, Illinois, U.S.A.

7) Sayed, H. Y., Mohamed, H. A., \& Mohamed, E. E. (2013). Patients' Perceptions as Indicators of Quality of Nursing Service Provided at Al Noor Specialist Hospital at Makkah Al Moukarramah, KSA. Journal of American Science, 9 (5), 71-78.

8) Zarei, A., Arab, M., Froushani, A. R., Rashidian, A., \& Tabatabaei, S. M. (2011). Hospital services quality from patients' point of view: a cross - sectional study in Tehran private hospitals. Payavard Salamat, 5 (4), 66-76.

9) Zarei, A., Arab, M., Froushani, A. R., Rashidian, A., \& Tabatabaei, S. M. (2012). Service Quality of Private Hospitals: The Iranian Patients' Perspective. BMC Health Services Research, 1-7. 